\title{
Global View of HIV Prevalence in Prisons: A Systematic Review and Meta-Analysis
}

\author{
Mehdi SAYYAH ${ }^{1}$, Fakher RAHIM ${ }^{2}$, Gholam Abbas KAYEDANI ${ }^{3,4}$, Kiarash \\ SHIRBANDI ${ }^{5}$, Amal SAKI-MALEHI ${ }^{6}$
}

1. Education Development Center (EDC), Ahvaz Jundishapur University of Medical Sciences, Abvaz, Iran

2. Research Center of Thalassemia \& Hemoglobinopathy, Health Research Institute, Abvaz Jundishapur University of Medical Sciences, Abvaz, Iran

3. Health Research Institute, Infectious and Tropical Diseases Research Center, Abvaz Jundishapur University of Medical Sciences, Abvaz, Iran

4. Department of Virology, School of Medicine, Abvaz Jundishapur University of Medical Sciences, Abvaz, Iran

5. Systematic Review and Meta-Analysis Expert Group (SRMEG), Universal Scientific Education and Research Network (USERN), Abvaz, Iran

6. Department of Biostatistics and Epidemiology, School of Health, Abvaz Jundishapur University of Medical Sciences, Abvaz, Iran

*Corresponding Author: Email: Bioinfo2003@gmail.com

(Received 12 Feb 2018; accepted 20 Apr 2018)

\begin{abstract}
Background: We aimed to estimate the global prevalence of HIV, as well as cross-countries comparison in people who are in prison.

Methods: We systematically assessed published studies reporting HIV prevalence among prisoners in the world. We searched international datasets banks, including PubMed, SCOPUS, Cumulative Index to Nursing and ISI web of science along with local databases and included original articles reporting data on the prevalence of HIV from 1980 to 2017.

Results: We included 72 studies that reported HIV prevalence for 2,275,930 adult male and female prisoners. The pooled estimate of HIV prevalence was 3.4\% (95\% CI 3.2\%-3.6\%); however, the prevalence of HIV across individual studies varied considerably (ranging from 0 in Bosnia and Herzegovina to More than $20 \%$ in Iran, Zambia, Spain) and statistical heterogeneity was substantial (I2=0.99, $\mathrm{Q}=121 ; P<0.0001)$. The prevalence of HIV among prisoners in the continents Asia, Africa, North America and Europe was estimated as 3.0\% (95\% CI 3.3\%-4.3\%), 6\% (95\% CI -0.0\%-2.0\%), 4\% (95\% CI 3.0\%-4.0\%), 5.0\% (95\% CI 0.0\%-11\%), respectively. Conclusion: Protecting prisoners' health protects general public health. Successful HIV preventive measures in prisons include provision of HIV education and information; clean needles and syringes; drug treatment; and condoms. Governments have a moral and ethical obligation to prevent the spread of HIV/AIDS in prisons and to provide compassionate care, treatment and support for those infected.
\end{abstract}

Keywords: HIV; Global; Systematic review, Meta-analysis; Prevalence; Prisoners

\section{Introduction}

$\mathrm{HIV} / \mathrm{AIDS}$ is a global problem that presents in different age groups and races, not only in homosexuals but in both sexes (1). Over the past few years, the issue of controlling high-risk diseases has been pursued among the prisoners to the detriment, and there are many efforts have been 
made since the prison environment is closed and the conditions for the transmission of contagious diseases are very much in place (2). HIV prevalence among prisoners has been reported to vary between different countries from $0 \%-2 \%$ in Australia to 2\% in America, 11\% in Latin American countries, $10 \%$ in the Middle East, and 20\% in African countries (3). Despite the fact that addicts and drug offenders in prisons account for considerable part of the prison population, the number of people infected with HIV is higher, but the pace of its expansion is increasing (4).

"Such measurement also enables direct comparison of different HIV metrics, emphasizing the specific needs of each geographic region and allowing for a more targeted response to the epidemic" (5). Authorities should put urgent measures to prevent the transmission of HIV at the national level in the country's agenda and plans because it will be too late tomorrow (5).

We aimed to estimate the global prevalence of HIV, as well as cross-countries comparison in people who are in prison.

\section{Methods}

\section{Search strategy}

We performed a comprehensive search through international indexing databases, including PubMed, Scopus, Cochrane Library, PsycINFO, CINAHL, ISI Web of Science, Science Direct from inception, and Embase; moreover, local databases include SID (Scientific Information database, Magiran, and IRANDOC, were searched using both Persian and English keywords. The search was conducted from 1980 to 2017 with no language limit. Searched was performed using the following keywords: (HIV or Human Immunodeficiency Virus or AIDS or Acquired Immune Deficiency Syndrome) and (prison or Prisoner) and (epidemiology or prevalence or incidence). In addition, to find more eligible studies the reference lists of relevant publications were manually searched. Studies that fulfilled defined criteria, including observational studies (prospective co- hort, retrospective cohort, case-control, or crosssectional) and reporting the prevalence of HIV among prisoners, which full-text was accessible, were considered in the meta-analysis. Other article types include reviews (narrative or systematic), commentaries, letters to the editor, case series or case reports, and pooled analyses of original data were excluded.

\section{Data extraction}

Data were collected using a data extraction form, including first author name, publication year, location, study design, sample size, demographic characteristics such as age and sex, and criteria for enrolling. Two authors (F.R. and K.SH.) separately extracted the information of interest from studies. We contacted the authors of the eligible articles for missing data, if necessary.

\section{Statistical analysis}

Heterogeneity was tested using both $I^{2}$ statistic and Chi-square test. $I^{2}>50 \%$ or $P<0.05$ were considered to exhibit significant heterogeneity. Furthermore, funnel plot and Egger's regression test was implemented to assess publication bias. Stata 13 was used to provide pooled estimations, with corresponding $95 \% \mathrm{CI}$ and plots.

\section{Results}

We found 3851 potentially relevant studies, of which 181 met our criteria and 72 articles (Fig. 1) (6-83), were included. Seventy-two selected studies enrolled 2,275,930 adult male and female prisoners. Of them, 32 were from Asia, 31 from North America, 5 from Europe, and 4 from Africa. The majority of included articles $(n=64)$ were cross-sectional studies that assessed the prevalence of HIV among prisoners. Utmost included articles stated little to no information on possible factors accompanying with HIV prevalence. The results of our quality assessment alongside the evaluation criteria were summarized, that showed in most of the items more than $65 \%$ of criteria were fulfilled. 


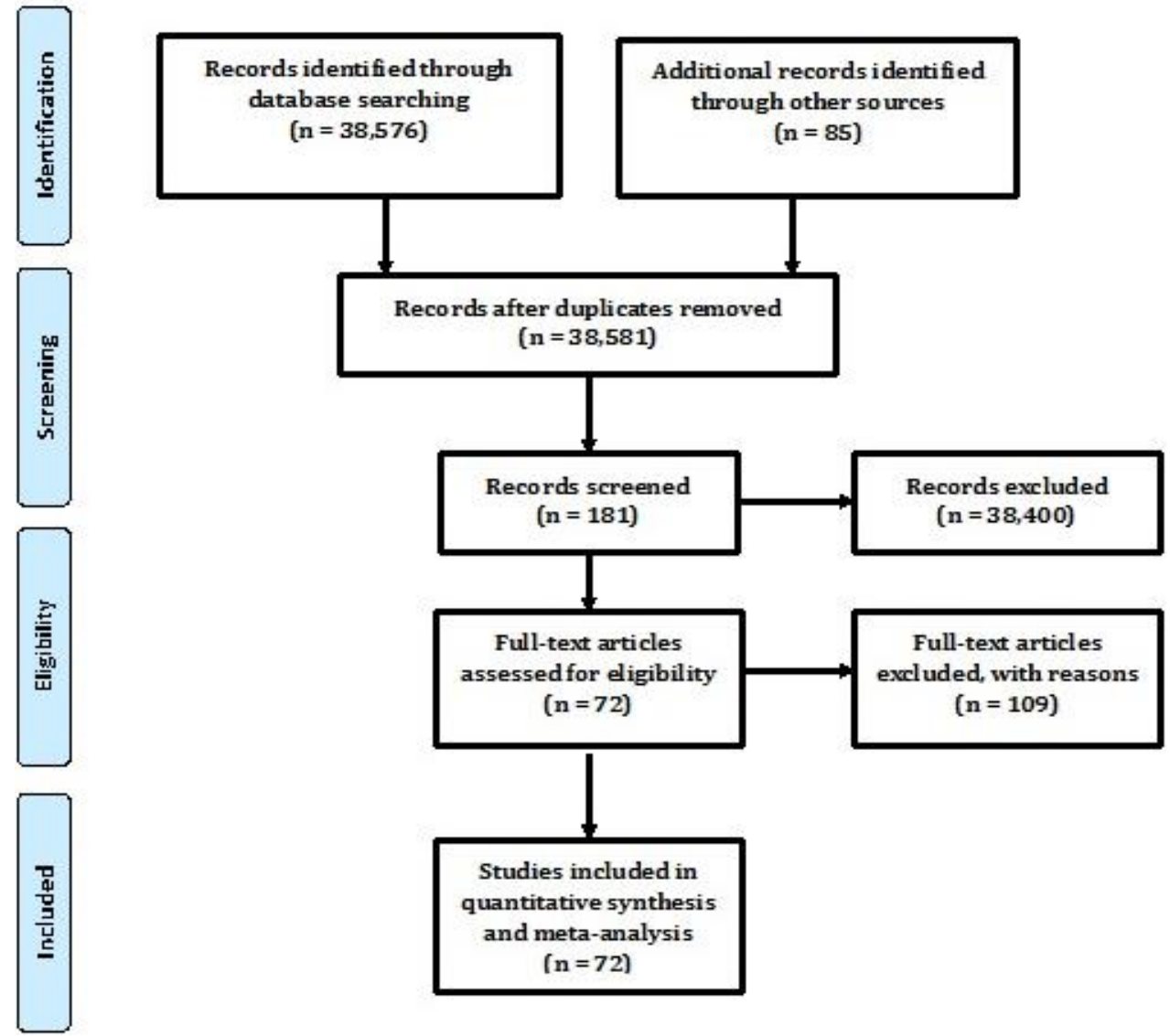

Fig. 1: Study selection process, systematic review of HIV prevalence among prisoners

The pooled estimate of HIV prevalence was $3.4 \%$ ( $95 \%$ CI 3.2\%-3.4\%); however, the prevalence of HIV across individual studies varied considerably (ranging from 0 in Bosnia and Herzegovina to More than $20 \%$ in Zambia) and statistical heterogeneity was substantial $\left(I^{2}\right.$
$=0.99, \mathrm{Q}=1 ; P<0.0001)$, Egger's test revealed that there is significant publication bias $(\mathrm{t}=7.09$; $P<0.0001)$. The result of sensitivity analysis showed that pooled estimate of HIV prevalence was $2 \%(95 \%$ CI 2\%-3\%) (Table 1, Fig. 2).

Table 1: Country-based pooled analysis of the prevalence of HIV among prisoners

\begin{tabular}{|c|c|c|c|c|c|c|c|c|c|}
\hline \multirow[t]{2}{*}{ Location } & \multirow[t]{2}{*}{$\boldsymbol{N}$} & \multicolumn{2}{|c|}{ Heterogeneity test } & \multirow[t]{2}{*}{$I^{2}$} & \multicolumn{2}{|c|}{ Egger's Test } & \multirow[t]{2}{*}{$P(95 \% C I)$} & \multicolumn{2}{|c|}{ test $(s)$ of $P=0$} \\
\hline & & Q Cochrane & $P$-value & & Bias & $P$-value & & $Z$ & $P$-value \\
\hline Asia & 32 & 2319.62 & $<0.0001$ & $98.15 \%$ & 9.28 & 0.79 & $\begin{array}{c}0.03 \\
(0.033,0.043)\end{array}$ & 19.49 & $<0.0001$ \\
\hline Africa & 4 & 576.93 & $<0.0001$ & $99.5 \%$ & 7.23 & $<0.0001$ & $\begin{array}{c}0.06 \\
(0.0,0.20)\end{array}$ & 1.92 & 0.05 \\
\hline $\begin{array}{l}\text { North } \\
\text { America }\end{array}$ & 31 & 5555.62 & $<0.0001$ & $99.5 \%$ & 5.88 & 0.19 & $\begin{array}{c}0.04 \\
(0.03,0.04)\end{array}$ & 30.07 & $<0.0001$ \\
\hline Europe & 5 & 503.38 & $<0.0001$ & $99 \%$ & 7.39 & $<0.0001$ & $\begin{array}{c}0.05 \\
(0.0,0.11)\end{array}$ & 2.6 & 0.01 \\
\hline Overall & 72 & 14613.19 & $<0.0001$ & $99.43 \%$ & 7.09 & $<0.0001$ & $\begin{array}{c}0.034 \\
(0.032,0.036)\end{array}$ & 33.34 & $<0.0001$ \\
\hline
\end{tabular}




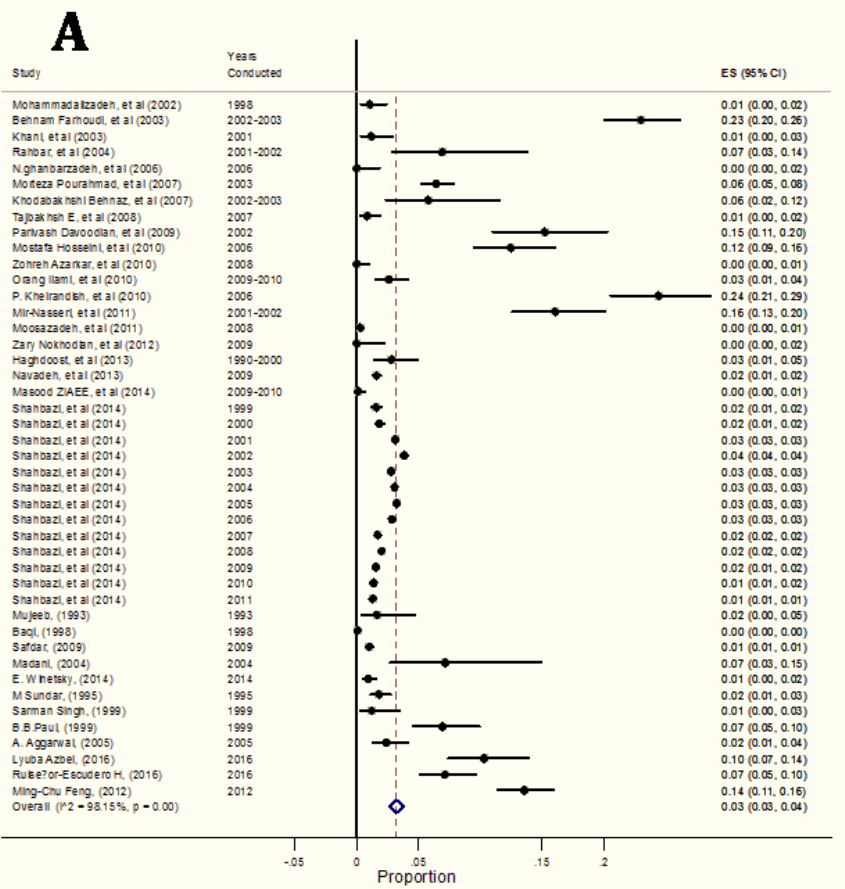

C

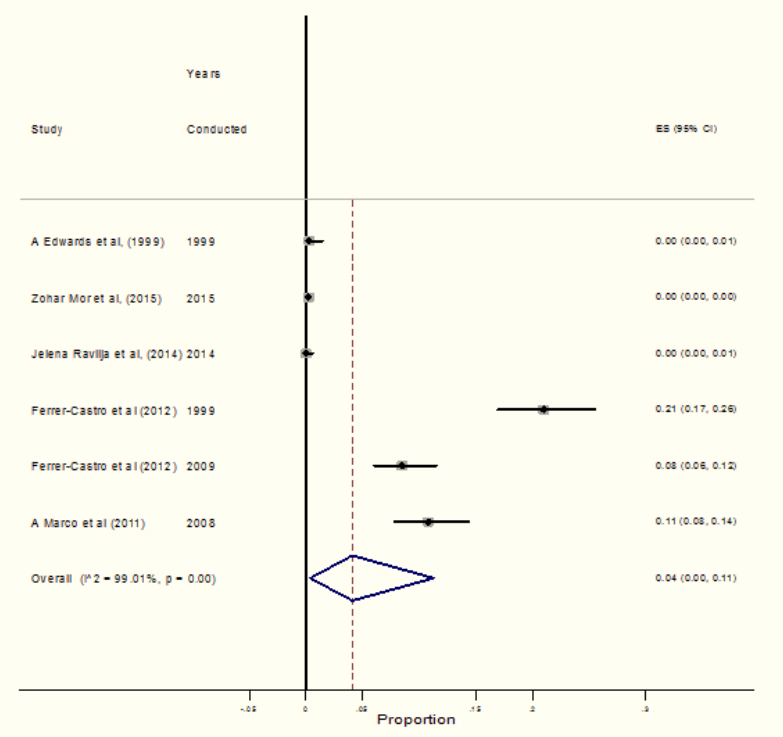

B

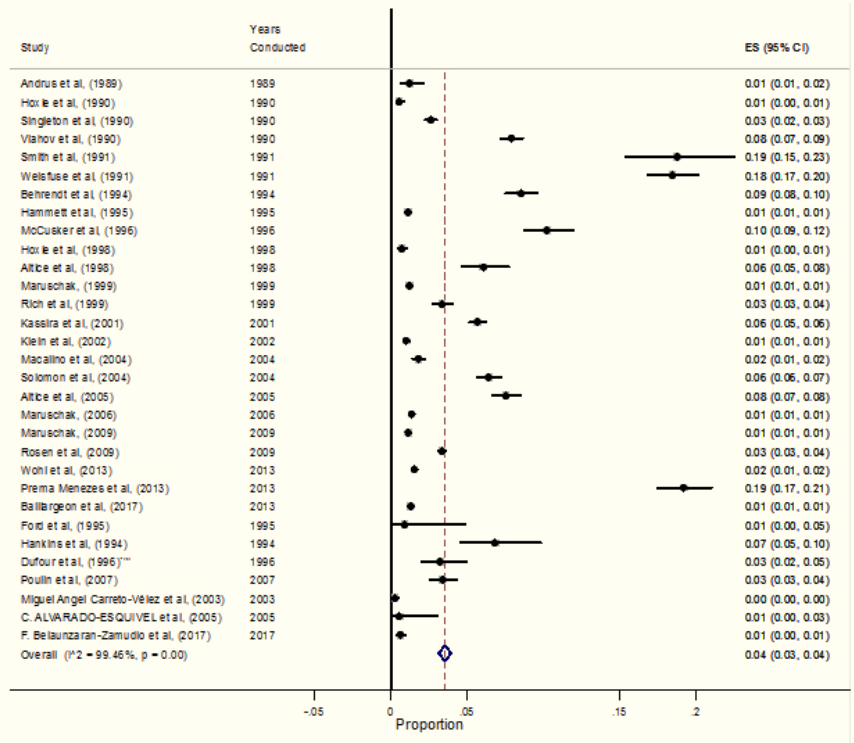

D

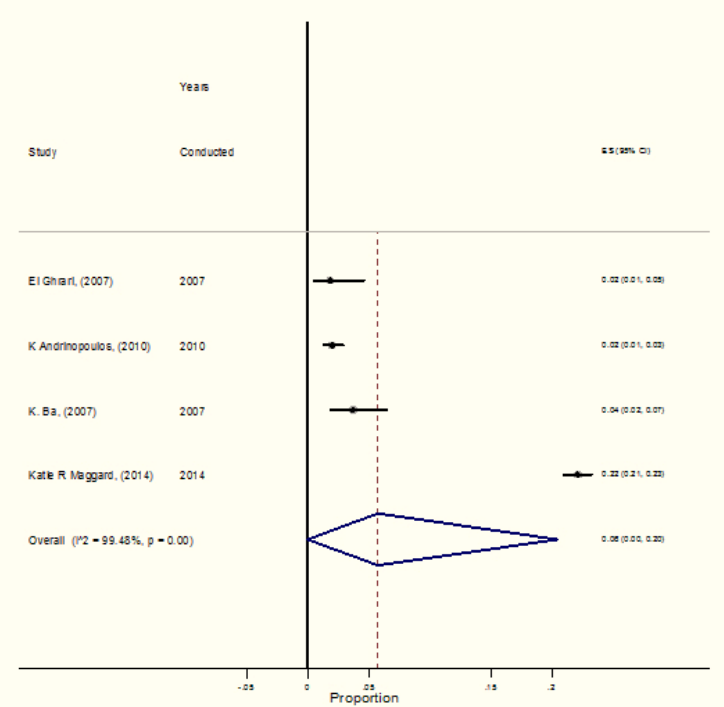

Fig. 2: Forest plot for the overall prevalence of HIV among A. Asian prisoners B. North American prisoners C. European prisoners D. African prisoners. Each study is shown by the point estimate of the prevalence (p) and 95\% confidence interval for the $\mathrm{p}$ (extending lines); the pooled $\mathrm{p}$ and $95 \%$ confidence interval by random-effects calculations are depicted as a diamond

Three Asian countries showed the HIV prevalence among prisoners greater than $10 \%$, including Iran $(15 \%$ in Southern region (24)), Kyrgyzstan (10.3\%) (13), and Taiwan (13.5\%) 
(29). Among North American countries, some region of USA showed the HIV prevalence among prisoners greater than 10\% (18.75\%) (73); while in Europe countries, three showed the HIV prevalence among prisoners greater than $10 \%$, including Spain (21\%) (30), Estonia (16\%) (6), and Ukraine $(14.5 \%)(6)$. The pooled prevalence of HIV among prisoners in the continents Asia, Africa, North America and Europe was estimated as $3.0 \%(95 \%$ CI $3.3 \%-4.3 \%), 6 \%(95 \%$ CI $0.0 \%-2.0 \%), 4 \% \quad(95 \%$ CI $3.0 \%-4.0 \%), \quad 5.0 \%$ (95\% CI 0.0\%-11\%), respectively (Table 1, Fig. 2).

\section{Discussion}

Although the discrimination and prejudice behavior in prisons in the world has exacerbated the spread of various diseases, including HIV/AIDS, among prisoners (2), few studies have been performed to document the prevalence of disease and associated behaviors among this population so far. This systematic review and meta-analysis included all available studies that reported on the prevalence of HIV among prisoners in the world.

HIV in many parts of the world is known more as a chronic disease than a lethal infectious disease (3). The HIV prevalence is different among various people, and both the number of CD4 cells and the viral load are useful in predicting outcomes (84). Without treatment, the survival time after HIV infection is estimated to be on average 9 to $11 \mathrm{yr}$, depending on the type of HIV (85). If the treatment begins after the diagnosis of HIV, life expectancy will be between 10 and $40 \mathrm{yr}$ (86). HIV is a global epidemic (87). HIV is more likely to be transmitted, through unprotected sexual intercourse and syringes and needles used for injection (88). The needle sharing HIV infection occur in $69.5 \%$ and via unprotected sexually transmitted intercourse is $10 \%$ of the general population $(89,90)$. Africa, especially in the countries of sub-Saharan region is known as the first leading HIV burden part of the world (91).

Today's, prisons are one of the well-known centers of focusing on HIV infection around the world, and not only prisoners are prone to HIV infection but they are considered as a reservoir for the onset and spread of HIV in the community. HIV-infection was presented in more than $10 \%$ of the general population in some African countries, including Botswana, Lesotho, Malawi, Mozambique, Namibia, South Africa, Swaziland, Zambia, and Zimbabwe (92). Our meta-analysis also showed a high HIV prevalence among prisoners in Africa. Although Asia that considers as the second major HIV burden, has important epidemiologic differences with Africa, the HIV incidence is declining in Asia as in sub-Saharan Africa. Unlike the high HIV prevalence in the general population and despite the high prevalence of AIDS in some regions of various Asian countries (93), our meta-analysis showed a low HIV prevalence among Asian prisoners.

\section{Conclusion}

People in prisons have the same right to health and health care, including preventive measures, as those outside, and their lives and health are connected to those outside in many ways. Protecting prisoners' health protects general public health. Successful HIV preventive measures in prisons include provision of HIV education and information; clean needles and syringes; drug treatment; and condoms. Governments have a moral and ethical obligation to prevent the spread of $\mathrm{HIV} / \mathrm{AIDS}$ in prisons and to provide proper and compassionate care, treatment and support for those infected.

\section{Ethical considerations}

Ethical issues (Including plagiarism, informed consent, misconduct, data fabrication and/or falsification, double publication and/or submission, redundancy, etc.) have been completely observed by the authors.

\section{Acknowledgements}

We would like to express our thanks to all corresponding authors of included studies. 


\section{Conflict of interest}

The authors declare that there is no conflict of interests.

\section{References}

1. Muula AS (2008). HIV infection and AIDS among young women in South Africa. Croat Med J, 49(3):423-35.

2. Hammett TM (2006). HIV/AIDS and other infectious diseases among correctional inmates: transmission, burden, and an appropriate response. Am J Public Health, 96(0):974-8.

3. Gańczak, Maria, and Zbigniew Szych (2017). $\mathrm{HBV}, \mathrm{HCV}$, and HIV infection prevalence among prison staff in the light of occupational risk factors. Medycyna Pracy, 68.4: 507-516.

4. Cropsey KL, Wexler HK, Melnick G et al (2007). Specialized Prisons and Services: Results From a National Survey. Prison J, 87:58-85.

5. Hanass-Hancock J, Chappell P, Myezwa $\mathrm{H}$ et al (2016). Committing to disability inclusion to end AIDS by 2030. Lancet HIV, 3(12):e556e557.

6. Roberts JM, Redman CW (1993). Pre-eclampsia: more than pregnancy-induced hypertension. Lancet, 341(8858):1447-51.

7. Aggarwal A, Arora U, Nagpal N (2005). Seroprevalence of HIV in central jail inmates of Amritsar. Indian J Community Med, 30(4):2.

8. Altice FL, Marinovich A, Khoshnood K et al (2005). Correlates of HIV infection among incarcerated women: implications for improving detection of HIV infection. $J$ Urban Health, 82(2):312-26.

9. Altice FL, Mostashari F, Selwyn PA et al (1998). Predictors of HIV infection among newly sentenced male prisoners. I Acquir Immune Defic Syndr Hum Retrovirol,18(5):444-53.

10. Alvarado-Esquivel C, Sablon E, Martinez-Garcia S, Estrada-Martínez S (2005). Hepatitis virus and HIV infections in inmates of a state correctional facility in Mexico. Epidemiol Infect, 133(4):679-85.

11. Andrinopoulos K, Kerrigan D, Figueroa J et al (2010). Establishment of an HIV/sexually transmitted disease programme and prevalence of infection among incarcerated men in Jamaica. Int J STD AIDS, 21(2):114-9.

12. Andrus JK, Fleming DW, Knox C et al (1989). HIV testing in prisoners: is mandatory testing mandatory? Am J Public Health, 79(7):840-2.

13. Azbel L, Polonsky M, Wegman M et al (2016). Intersecting epidemics of HIV, HCV, and syphilis among soon-to-be released prisoners in Kyrgyzstan: implications for prevention and treatment. Int J Drug Policy, 37:9-20.

14. Ba K, Keita M, Fall-Malick F et al (2015). Enquête comportementale et sérologique sur le VIH/sida chez les détenus à Nouakchott (Mauritanie). Bull Soc Pathol Exot, 108(3):20812.

15. Baillargeon J, Pulvino JS, Leonardson JE (2017). The changing epidemiology of HIV in the criminal justice system. Int $J$ STD AIDS;28(13):1335-40.

16. Baqi S, Nabi N, Hasan SN et al (1998). HIV antibody seroprevalence and associated risk factors in sex workers, drug users, and prisoners in Sindh, Pakistan. J Acquir Immune Defic Syndr Hum Retrovirol, 18(1):73-9.

17. Behnaz K, Abdollah A, Fateme F, Mohammadreza R (2007). Prevalence and risk factors of HIV, hepatitis B virus and hepatitis $C$ virus infections in drug addicts among Gorgan prisoners. Journal of Medical Sciences, 7(2):252-4.

18. Behrendt C, Kendig N, Dambita C et al (1994). Voluntary testing for human immunodeficiency virus (HIV) in a prison population with a high prevalence of HIV. Am J Epidemiol, 139(9):918-26.

19. Belaunzarán-Zamudio PF, Mosqueda-Gomez JL, Macias-Hernandez A et al (2017). Risk factors for prevalent hepatitis C virusinfection among inmates in a state prison system in Mexico. PloS One, 12(6):e0179931.

20. Carreto-Vélez MA, Carrada-Bravo T, MartínezMagdaleno A (2003). Seroprevalencia de $\mathrm{VHB}, \mathrm{VHC}$ y VIH en donadores de sangre en Irapuato, México. salud pública de méxico, 45(S5):690-3.

21. Control CfD (2008). Boibehavioural survey on HIV/AIDS among Khoozestan prisoners. Ministry of Health.

22. Control CfD (2008). Study of the prevalence of Neisseria Gonorrhoeae, Clamidia 
Trachomatis, Syphilis and HIV in Kerman prisoners. Ministry of Health.

23. Control CfD (2008). Boibehavioural survey on HIV/AIDS among Kermanshah prisoners. Ministry of Health.

24. Davoodian P, Dadvand H, Mahoori K (2009). Prevalence of selected sexually and bloodborne infections in Injecting drug abuser inmates of bandar abbas and roodan correction facilities, Iran, 2002. Braz J Infect Dis, 13(5):356-8.

25. Dufour A, Alary M, Poulin C et al (1996). Prevalence and risk behaviours for HIV infection among inmates of a provincial prison in Quebec City. AIDS, 10(9):1009-15.

26. Edwards A, Curtis S, Sherrard J (1999). Survey of risk behaviour and HIV prevalence in an English prison. Int J STD AIDS, 10(7):464-6.

27. El Ghrari K, Terrab Z, Benchikhi H (2007). Prevalence of syphilis and HIV infection in female prisoners in Morocco. East Mediterr Health J, 13(4):774-9.

28. Farhoudi B, Montevalian A, Motamedi M et al (2003). Human immunodeficiency virus and $\mathrm{HIV}$-associated tuberculosis infection and their risk factors in injecting drug users in prison in Iran. Tehran: Iran Ministry of Health.

29. Feng MC, Feng JY, Chen YH et al (2012). Prevalence and knowledge of sexual transmitted infections, drug abuse, and AIDS among male inmates in a Taiwan prison. Kaohsiung J Med Sci, 28(12):660-6.

30. Ferrer-Castro V, Crespo-Leiro M, GarciaMarcos L et al (2012). Evaluation of needle exchange program at Pereiro de Aguiar prison (Ourense, Spain): ten years of experience. Rev Esp Sanid Penit, 14(1):3-11.

31. Ford PM, White C, Kaufmann H et al (1995). Voluntary anonymous linked study of the prevalence of HIV infection and hepatitis $\mathrm{C}$ among inmates in a Canadian federal penitentiary for women. $C M A J, 153(11): 1605$.

32. Ghanbarzadeh N, Nadjafi-Semnani M (2006). A study of HIV and other sexually transmitted infections among female prisoners in Birjand. Journal of Birjand University of Medical Sciences, 13(3):9-15.

33. Haghdoost AA, Mirzazadeh A, Shokoohi M et al (2013). HIV trend among Iranian prisoners in 1990s and 2000s; analysis of aggregated data from HIV sentinel sero-surveys. Harm Reduct $J, 10: 32$.

34. Hankins CA, Gendron S, Handley $M$ et al (1994). HIV infection among women in prison: an assessment of risk factors using a nonnominal methodology. Am J Public Health, 84(10):1637-40.

35. Hoxie N, Chen MH, Prieve A et al (1998). HIV seroprevalence among male prison inmates in the Wisconsin Correctional System. WMJ, 97(5):28-31.

36. Hoxie NJ, Vergeront JM, Frisby HR et al (1990). HIV seroprevalence and the acceptance of voluntary HIV testing among newly incarcerated male prison inmates in Wisconsin. Am J Public Health, 80(9):1129-31.

37. Ilami O, Sarkari B, Khosravani A et al (2012). HIV seroprevalence among high-risk groups in Kohgiloyeh and Boyerahmad Province, Southwest of Iran, a behavioral surveillance survey. AIDS Behav, 16(1):86-90.

38. Diah Ayu N.H (2010), HIV and Syphilis Prevalence and Risk Behaviour Survey Among Prisoners in Prisons and Detention Centres in Indonesia. Theisis. Indonesia.

39. Kassira EN, Bauserman RL, Tomoyasu N et al (2001). HIV and AIDS surveillance among inmates in Maryland prisons. J Urban Health, 78(2):256-63.

40. Kazerooni A, Joolaei H, Parsa N (2010). Knowledge and attitude of male intravenous drug users on HIV/AIDS associated high risk behaviors in Shiraz Pir-Banon jail, Fars Province, Southern Iran. IRCMJ, 334-6.

41. Khamispoor G, Tahmasebi R (1999). Prevalence of HIV, HBV, HCV and syphilis in high risk groups of Bushehr province (Farsi). Iran South Med J, 1:59-3.

42. Khani M, Vakili MM (2003). Prevalence and risk factors of HIV, hepatitis B virus and hepatitis $\mathrm{C}$ virus infections in drug addicts among Zanjan prisoners. ARCHIVES OF IRANLAN MEDICINE, 6(1):1-4.

43. Klein SJ, O'Connell DA, Devore BS, Wright LN, Birkhead GS (2002). Building an HIV continuum for inmates: New York State's criminal justice initiative. AIDS Educ Prev, 14(5 Supplement B):114-23.

44. Poorasl AM, Vahidi R, Fakhari A et al (2007). Substance abuse in Iranian high school students. Addict Behav, 32(3):622-7. 
45. Laith A, Francisca A, Iris $S$ et al (2010). Characterizing the HIV/AIDS Epidemic in the Middle East and North Africa (Appendix A). Washington: The World Bank.

46. Macalino GE, Vlahov D, Sanford-Colby $S$ et al (2004). Prevalence and incidence of HIV, hepatitis B virus, and hepatitis C virus infections among males in Rhode Island prisons. Am J Public Health, 94(7):1218-23.

47. Madani TA, Al-Mazrou YY, Al-Jeffri MH, Al Huzaim NS (2004). Epidemiology of the human immunodeficiency virus in Saudi Arabia; 18-year surveillance results and prevention from an Islamic perspective. $B M C$ Infect Dis, 4:25.

48. Maggard KR, Hatwiinda S, Harris JB et al (2015). Screening for tuberculosis and testing for human immunodeficiency virus in Zambian prisons. Bull World Health Organ, 93(2):93-101.

49. Maruschak L (2009). HIV in prisons -W, DC: US Department of Justice, Bureau of Justice Statistics, Report no. 228307.

50. Maruschak L (2006). HIV in prisons W, DC: US Department of Justice, Office of Justice Programs, Report no. 213897.

51. McCusker J, Willis G, McDonald M et al (1996). Community-wide HIV counselling and testing in central Massachusetts: who is retested and does their behavior change? $J$ Community Health, 21(1):11-22.

52. Menezes P, Rosen D, Wohl DA et al (2013). Low prevalence of antiretroviral resistance among HIV type 1-positive prisoners in the Southeast United States. AIDS Res Hum Retroviruses, 29(1):136-41.

53. Mir-Nasseri MM, MohammadKhani A, Tavakkoli H et al (2011). Incarceration is a major risk factor for blood-borne infection among intravenous drug users. Hepat Mon, 11(1):19-22.

54. Moosazadeh M, Amiresmaili M, Parsaei M et al (2011). Prevalence of tuberculosis among the prisoners of Mazandaran. JRUMS, 10(4):30916.

55. Mor Z, Eisenberg JR, Grotto I, Tishler-Aurkin D (2015). HIV/AIDS prevalence in Israeli prisons: Is there a need for universal screening? J Public Health Policy, 36(4):484 90.
56. Mujeeb SA, Hafeez A (1993). Prevalence and pattern of HIV infection in Karachi. J Pak Med Assoc, 43:2-.

57. Navadeh S, Mirzazadeh A, Gouya MM et al (2013). HIV prevalence and related risk behaviours among prisoners in Iran: results of the national biobehavioural survey, 2009. Sex Transm Infect, iii33-6.

58. Nokhodian Z, Yazdani MR, Yaran M et al (2012). Prevalence and risk factors of HIV, syphilis, hepatitis B and C among female prisoners in Isfahan, Iran. Hepat Mon, 12(7):442-447.

59. Pal B, Acharya A, Satyanarayana K (1999). Seroprevalence of HIV infection among jail inmates in Orissa. Indian J Med Res, 109:199201.

60. Poulin C, Alary M, Lambert G et al (2007). Prevalence of HIV and hepatitis C virus infections among inmates of Quebec provincial prisons. CMAJ, 177(3):252-6.

61. Pourahmad M, Javady A, Karimi I et al (2007). Seroprevalence of and risk factors associated with hepatitis B, hepatitis $C$, and human immunodeficiency virus among prisoners in Iran. IDCP, 15(6):368-72.

62. Rahbar AR, Rooholamini S, Khoshnood K (2004). Prevalence of HIV infection and other blood-borne infections in incarcerated and non-incarcerated injection drug users (IDUs) in Mashhad, Iran. Int J Drug Policy, 15(2):151-5.

63. Ravlija J, Vasilj I, Marijanović I, Vasilj M (2014). Risk behaviour of prison inmates in relation to HIV/STI. Psychiatr Danub, 395-401.

64. Reekie JM, Levy MH, Richards AH et al (2014). Trends in prevalence of HIV infection, hepatitis B and hepatitis $\mathrm{C}$ among Australian prisoners-2004, 2007, 2010. Med J Aust, 200(5):277-80.

65. Rich JD, Holmes L, Salas C et al (2001). Successful linkage of medical care and community services for HIV-positive offenders being released from prison. J Urban Health, 78(2):279-89.

66. Rosen DL, Schoenbach VJ, Wohl DA et al (2009). Characteristics and behaviors associated with HIV infection among inmates in the North Carolina prison system. Am J Public Health, 99(6):1123-30. 
67. Safdar S, Mehmood A, Abbas SQ (2009). Prevalence of HIV/AIDS among jail inmates in Sindh. JPMA, 59(2):111-2.

68. SeyedAlinaghi S, Kheirandish P, Javid GE et al (2010). Prevalence and correlates of coinfection with human immunodeficiency virus and hepatitis $C$ virus in male injection drug users in Iran. Arch Iran Med, 13(4):31823.

69. Sgarbi RVE, Carbone AdSS, Paião DSG et al (2015). A cross-sectional survey of hiv testing and prevalence in twelve brazilian correctional facilities. PloS One, 10(10):e0139487.

70. Shahbazi M, Farnia M, Rahmani K, Moradi G (2014). Trend of HIV/AIDS prevalence and related interventions administered in prisons of Iran-13 years' experience. Iran J Public Health, 43(4):471-479.

71. Singh S, Prasad R, Mohanty A (1999). High prevalence of sexually transmitted and bloodborne infections amongst the inmates of a district jail in Northern India. Int J STD AIDS, 10(7):475-8.

72. Singleton J, Perkins C, Trachtenberg A et al (1990). HIV antibody seroprevalence among prisoners entering the California correctional system. West J Med, 153(4):394-399.

73. Smith PF, Mikl J, Truman BI et al. HIV infection among women entering the New York State correctional system. Am J Public Health. 1991;81(Suppl):35-40.

74. Solomon L, Flynn C, Muck K, Vertefeuille J (2004). Prevalence of HIV, syphilis, hepatitis $\mathrm{B}$, and hepatitis $\mathrm{C}$ among entrants to Maryland correctional facilities. J Urban Health, 81(1):25-37.

75. Sundar M, Ravikumar K, Sudarshan M (1995). A cross-sectional seroprevalence survey for HIV-1 and high risk sexual behaviour of seropositives in a prison in India. Indian J Public Health, 39(3):116-8.

76. Tajbakhsh E, Yaghubi R (2008). Serologic evaluation of HIV contamination in Shahrekord prisoners through ELISA and Western blot. SJIBTO, 4(5):365-8.

77. Vlahov D, Muñoz A, Brewer F et al (1990). Seasonal and annual variation of antibody to HIV-1 among male inmates entering Maryland prisons: update. $A I D S, 4(4): 345-50$.
78. Weisfuse IB, Greenberg BL, Back SD et al (1991). HIV-1 infection among New York City inmates. AIDS, 5(9):1133-8.

79. Widom R, Epstein J, Gross M et al. (1994). update: HIV/AIDS and STDs in correctional facilities. Washington, DC: US Department of Justice, Office of Justice Programs, National Institute of Justice, 1995. NCJ, 156832.

80. Winetsky DE, Almukhamedov O, Pulatov D et al (2014). Prevalence, risk factors and social context of active pulmonary tuberculosis among prison inmates in Tajikistan. PLoS One, 9(1):e86046.

81. Wohl DA, Scheyett A, Golin CE et al (2011). Intensive case management before and after prison release is no more effective than comprehensive pre-release discharge planning in linking HIV-infected prisoners to care: a randomized trial. AIDS Behav, 15(2):356-64.

82. Ziaee M, Sharifzadeh G, Namaee $M H$, Fereidouni M (2014). Prevalence of HIV and Hepatitis B, C, D infections and their associated risk factors among prisoners in Southern Khorasan Province, Iran. Iran J Public Health, 43(2):229-34.

83. Zohreh A, Gholamreza S (2010). Evaluation of the prevalence of hepatitis $B$, hepatitis $C$, and $\mathrm{HIV}$ in inmates with drug-related convictions in Birjand, Iran in 2008. Hepat Mon, 26-30.

84. Grassly NC, Garnett GP, Schwartlander B et al (2001). The effectiveness of HIV prevention and the epidemiological context. Bull World Health Organ, 79(12):1121-32.

85. Ferreira MM, Ferrazoli L, Palaci M et al (1996). Tuberculosis and HIV infection among female inmates in Sao Paulo, Brazil: a prospective cohort study. J Acquir Immune Defic Syndr Hum Retrovirol, 13(2):177-83.

86. Chang JW, Min BK, Kim BS, Chang WS, Lee YH (2015). Neurophysiologic correlates of sonication treatment in patients with essential tremor. Ultrasound Med Biol, 41(1):12431.

87. Cohen MS, Hellmann N, Levy JA, DeCock K, Lange J (2008). The spread, treatment, and prevention of HIV-1: evolution of a global pandemic. J Clin Invest, 118(4):1244-54.

88. Shaw GM, Hunter E (2012). HIV Transmission. Cold Spring Harb Perspect Med, 2(11):a006965.

89. Des Jarlais DC (1997). HIV / STDs and drug use. AIDS STD Health Promot Exch, (2):1-3. 
90. Armstrong G, Humtsoe C, Kermode M (2011). HIV risk behaviours among injecting drug users in Northeast India following scale-up of a targeted HIV prevention programme. BMC Public Health, 11(0):S9.

91. Kharsany ABM, Karim QA (2016). HIV Infection and AIDS in Sub-Saharan Africa: Current Status, Challenges and Opportunities. Open AIDS J, 10:34-48.
92. Chen L, Jha P, Stirling B et al (2007). Sexual risk factors for HIV infection in early and advanced HIV epidemics in sub-Saharan Africa: systematic overview of 68 epidemiological studies. PLoS One, 2(10):e1001.

93. Shao Y, Williamson C (2012). The HIV-1 Epidemic: Low- to Middle-Income Countries. Cold Spring Harb Perspect Med, 2(3):a007187. 